\title{
Çatışma Teorisi Bağlamında Tarihsel-Toplumsal Çatışmanın Değişen Biçimleri Üzerine Bir İnceleme
}

\author{
DOI: 10.26466/opus.629985
}

\section{İnan Akdağ ${ }^{*}$}

* Dr. Öğr. Üyesi, Amasya Üniversitesi, Merzifon İ̈BF, Siyaset Bilimi ve Kamu Yönetimi Bölümü, Merzifon/Amasya/Türkiye

E-Posta: inanakdag@yahoo.com

ORCID: 0000-0001-5531-403X

\section{Öz}

Toplumsal dünya, farklılıklardan oluşmaktadır. Bu farklllıklar, farklı çıkarlar temelinde birbirinden ayrışmaktadır. Farklılklar arasında sürekli olarak çıkar çatışması gerçekleşmektedir. Bu çatışma, toplumsal çatışmaya yol açmaktadır. Toplumsal çatışma için, yalnızca, farklı çıkarlara sahip grupların olması yetmemektedir; aynı zamanda bu farklı çıkarlara sahip grupların bunun bilincinde olması gerekmektedir. Bu bağlamda, tarihsel olarak, farklı toplumsal çatışma biçimleri gerçeklik kazanmıştır. Çatışmalar, tarihsel olarak, ekonomi, ideoloji ve politik başat biçimler almıştır. Farklı toplumsal çatışma biçimlerinin ortaya çımasinda en önemli etken, bir ekonomik sistem olarak kapitalizmdir. Kapitalizm, toplumsal çatışmaları farklı biçimlerde şekillendirmektedir. Modern kapitalizm ortaya çıktıktan sonra toplumsal çatışma, tarihsel olarak, farklı biçimler almıştır. Bu çalışmada amaç, çıkar grupları arasındaki toplumsal çatışmaların farklı biçimlerini ortaya koymaktır. Çalışmanın hipotezi; tarihsel olarak toplumsal çatışma, sanayi devriminden 19. yy sonuna kadar ekonomi başat, 19. yy sonundan 1968'e kadar ideoloji başat ve 1968'den günümüze kadar politik başat biçimler almıştır. Çalışmanın birinci bölümünde kuramsal olarak toplumsal çatışmanın aldığı biçimler tartışlacak; ikinci bölümde kapitalizmin, siyasetin ve ideolojinin evrimi incelenecek; son olarak ise ekonomik, politik ve ideolojik toplumsal çatışmanın gelişimi ayrıtıll ele alınacaktır.

Anahtar Kelimeler: Çatışma, Çatışma Teorisi, Toplumsal Çatışma, Ekonomik Çatışma, Politik Çatışma 


\title{
An Analysis on Changing Forms of Historical-Social Conflict in the Context of Conflict Theory
}

\begin{abstract}
Social World consists of differences. These differences distinguish in the basis of different interests each other. Continuous interests clashes realizes among differences. This clash leads to social conflict. It is not enough that there are different interest groups, at the same time, it is necessary to be conscious of different interest groups. In this context, historically, different social conflict gains reality. Conflicts had historically taken economic dominant, ideological dominant and political dominant forms. The main effect of appearance of different social conflict forms is capitalism as an economic system. Capitalism differently shapes social conflict. Social conflict after the birth of modern capitalism had historically taken different types. The aim of this study is to put forward different types of social conflicts among interest groups. The hypothesis of this study is that social conflict had historically taken economy dominant from industrial revolution to the end of 19 century; then ideology dominant from the end of 19 century to 1968; finally, politic dominant from 1968 to todays. The first part of this study is to theoretically discuss types of social conflict; the second part of this study is to analyze the evolution of capitalism, politics and ideology; the third part of this study is to elaborate progress of economic, political and ideological social conflicts.
\end{abstract}

Keywords: Conflict, Conflict Theory, Social Conflict, Economic Conflict, Political Conflict 


\section{Giriş}

Çatışma teorisi, gündelik hayatın farklılıklardan oluştuğunu ve bu farklılıkların, uyumsuz çıkarlar sebebiyle birbiriyle çatışmalarından örüntülendiğini kuramsallaştırmıştır. Mikro seviyede aileden başlayarak, mezzo ve makro gruplara kadar toplum, bünyesinde, gerilimler ve çatışmalar taşımaktadır. Çatışma teorisi, farklı insanlar ve farklı grupların uyumsuz ihtiyaç ve çıkarlarını vurgulamaktadır (Johnson, 2008, s.367). Çatışma, toplumsal hayatın tüm katmanlarında varlığını sürdürmektedir. Toplumsal cinsiyet, etnik çatışmalar, dinsel çatışmalar, uluslararası çatışmalar ve sınıflar arası çatışmalar ilk bakışta karşımıza çıkan, toplumsal çatışmanın fay hatlarıdır. İndirgeme yapmak gerekirse, en yaygın çatışma, D. P. Johnson'a göre (2008, s. 367); kıt materyallerin dağıtımı ve finansal kaynaklar üzerine olan çatışmadır. Bir başka ifadeyle temel çatışma, ekonomi üzerinden yaşanan çatışmadır. Ancak çatışma, özellikle 20. yy'ın sonlarına doğru, ideolojik ve politik bir biçim almıştır.

Çatışma teorisine göre; çatışma, bir süreçtir. Bir grup, aktif mücadele için mobilize olana kadar, çatışan çıkarlar gizlidir (Borgatta ve Montgomery, 2000, s.415). Dolayısıyla dünya, farklılıklar üzerinden toplumsal hayatı kurgularken, yalnız farklılıkların olması, çatışma teorisi için, yeterli değildir. Çatışma teorisi için gerekli olan, bu farklılıkların bilincine ulaşan bir çıkar grubunun, mücadele için harekete geçmesidir. Bilinç ve pratik, çatışma sürecini tamamlayan unsurlar olarak karşımıza çımaktadır.

Çatışma teorisi, uzun yıllar boyunca Karl Marx ve Marksizmle özdeşleşmiştir. Sınıf çatışmasını, tarihin gelişim motoru olarak tanımlayan Marx, diyalektik olarak zıtların çatışmalı birliğini evrensel olarak belirlemiştir (Marx ve Engels, [1848] 2008). Bu anlamda çatışma, toplumsal yapıyı kurması ve sürdürmesi açısından, temel bir işleve sahiptir. Bunun yanı sıra Marksist olmayan çatışma teorisi ise, özellikle 1968'de ortaya çıkan küresel hareketlerinden sonra önem kazanmıştır. 1968 sonrası, tek başına Marksizmin ekonomi temelli sınıf çatışmasını değil, diğer toplumsal grupları (gender, etnisite, dinsel, medeniyetler vs.) içine alan çatışma teorileri geliştirilmiştir. M. Savur'a göre (1975, s.29) Marksizm ile çağdaş çatışma teorileri arasındaki temel farklılık; Karl Marx'ın sınıf çatışması anlayışını ileri sürerken, çağdaş çatışma teorisyenlerinin, çıkarların çatışmasını vurgulamasından kaynaklanır. Bu bakımdan çağdaş çatışma teorisyenleri, Marksizmin 
ekonomik temelli sınıf çatışması yerine toplumsal çatışmayı, daha geniş perspektiften ele almıştır.

Çatışma teorilerinin tarihsel gelişimi, modern dönemlerin başlarına kadar gitmektedir. Modern anlamda çatışma teorisi, Niccolo Machiavelli ile başlamaktadır (Savur, 1975, s.30). Machiavelli'ye göre ([1532] 2008, s.54) işgal edilen topraklarda yaşayan insanların farklı dil, yaşam biçimi ve düzeni, çatışmanın kaynaklarıdır. Bu çerçevede Machiavelli'nin, toplumsal çatışmayı, kültürel bağlamda kabul ettiği ileri sürebilir. Bu düşüncenin aksine, Manorama Savur (1975, s.31), Machiavelli'nin aslında kapitalizmin doğum sanciları sırasında ünlü eserini yazdığını ve ona göre toplumsal çatışmanın temelinde kapitalizmin yoğunlaşması olduğunu belirtmiştir. Dolayısıyla Machiavelli, Savur'a göre; teorisini bir ekonomik sistem olarak kapitalizme dayandırmaktadır. Machiavelli'yi Thomas Hobbes takip etmiştir. Toplumun anarşi durumu tezinin en önemli savunucusu, şüphesiz Thomas Hobbes'dur. Hobbes'a göre ([1651] 1998) toplum öncesi doğa durumu, bir savaş durumudur. Herkes, herkesle savaş halindedir. Kıskançlık temel güdüdür. Savaş durumunu engellemek için insanlar, toplum sözleşmesi aracılığı ile hakların üstün bir egemene, bir başka ifadeyle Leviathan olarak tanımladığ 1 devlete devretmiştir. Dolayısıyla Hobbes'da çatışma, süreklilik arz eden bir durumdur. 19. yy ile gerek toplumsal felsefi yaklaşım, gerekse de bilim olarak sosyoloji düşünürleri için en önemli tartışma alanını toplumsal dayanışmayı ortaya çıaran konular belirlemiştir. Çatışma olgusu bu anlamda üzerinde en sik durulan kavramlardan biri olmuştur. Karl Marx, toplumsal çatışmayı üretici güçler ve üretim ilişkileri bağlamında, iktisadi açıdan ele almıştır. Marx'a göre ([1859] 1993, s.9); "gelişmelerinin belirli bir aşamasında toplumun maddi üretici güçleri, o zamana kadar içinde hareket ettikleri mevcut üretim ilişkilerine, ya da bunların hukuki ifadesinden başka bir şey olmayan mülkiyet ilişkilerine ters düşerler... O zaman bir toplumsal devrim çağı başlar". Bu çerçevede Marx, üretici güçler olan emek ve sermaye arasında sınıflar bağlamında toplumsal çatışmayı tanımlamıştır. Çatışma durumu yanında, dayanışma tezinin en önemli savunucusu ise Emile Durkheim'dır. Durkheim'a göre ([1893] 2013) toplum, dayanışma üzerine kuruludur. Yalnızca dayanışma biçimi, işbölümüne bağlı olarak değişmiştir. Modern öncesi toplumlarda mekanik dayanışma söz konusu iken, modern toplumlarda gelişen işbölümü ile dayanışma, organik dayanışmaya dönüşmüştür. İşbölümü ile birlikte mesleklerin sayısı artmış ve bunun sonucunda 
ise insanların birbirine bağımlılığı artmıştır. Georg Simmel ([1908] 1956) ise çatışmanın, sosyal sistemlerin yaygın özelliği olduğunu belirtmekle birlikte çatışmanın, çıkarların çatışmasından daha fazlasını yansıttığını ve aynı zamanda, düşman içgüdülerin çatışmasından doğduğunu ileri sürmüştür. Max Weber'e göre ([1922] 2012, s.147) “sosyal bir ilişki, eylem bilerek diğer tarafın ya da tarafların direnmesine karşı aktörün kendi isteğinin yerine getirilmesine yöneltildiğinde çatışma olarak isimlendirilecektir". Weber ([1922] 2012, s.149), toplumda çatışmanın kaçınılmaz olduğunu belirtip, onu tamamıla ortadan kaldırmanın olanaksız olduğunu belirtmiş ve en barışçı bir düzen bile çatışma yollarını, çatışma konularını ve güdülerini ortadan kaldıramayacağını ileri sürmüştür.

Görüyoruz ki, çatışma teorisi ile ilgili klasik sosyologların yanında çağdaş sosyologların çok çeşitli tezleri olmuştur. Bu anlamda işlevselci yaklaşımın temsilcisi olarak kabul edilen Lewis Coser'e göre (1956, s.8) sosyal çatışma; muhaliflerin amaçlarının rakiplerini etkisizleştirmek, yaralamak veya bertaraf etmek olan kit statüler, iktidar ve kaynaklara ilişkin değerler ve iddialar üzerine mücadeledir. Ralf Dahrendorf'a göre ([1957] 1959, s.66) çağdaş sanayi toplumunda sınıf çatışması, sanayi toplumunun ilk ortaya çıkışından itibaren farklılık göstermiştir. Devlet ve sanayi girişimlerinde yaşanan değişim sonucu gerçekleşen çatışma düzenlemeleriyle birlikte çatı̧̧manın şiddeti yumuşamıştır. Kurumsallaşma arttıkça çatışmanın şiddeti azalmaktadır. Yine 1960'lara kadar etkin olan Amerikan yapısal işlevselciliği de çatışmayı dışlıyordu. En önemli temsilcisi Talcott Parsons'a göre (1951) toplum, değer uzlaşması üzerine kurulu bir topluluktur. 1960'larla birlikte, özellikle; 1968 toplumsal hareketleriyle birlikte çatışma teorisi yeniden gündeme gelmiştir. Sivil haklar protestosu, savaş karşıtı hareket, kadın hareketleri protestosu yeniden toplumsal çatışmayı gündeme getirmiştir (Berg ve Janoski, 2005, s.72). Çağdaş çatışma teorilerinden bir diğeri; davranışçı kuramdır. Davranışçı kurama göre; uyumsuz amaçlar, dayanışma, organizasyon, mobilizasyon, düşmanlık ve kaynaklar, çatışmacı davranışlara yol açmaktadır (Bartos ve Wehr, 2002, s.10). Davranışçı kuramın temsilcilerinden Randall Collins'e göre ([1975] 2009) çatışmanın ekseni, tabakalar arasındadır ve tabakaları da gruplar, etnisite ve eğitim durumu gibi değişkenler belirlemektedir. Çatışma, davranış farklılıklarından ortaya çıkmaktadır.

Diyebiliriz ki, çatışma teorisi ile ilgili literatür incelendiği zaman ortaya çıkan sonuç; çatışma teorisyenlerinin bütüncül çatışmanın aldığı biçimleri 
ortaya çıkarmaktansa sadece çatışma durumuna odaklanmış olmalarıdır. Çatışma tarif edilmiş, çatışma için gereken unsurlar sayılmış, toplum ile bağları belirlenmiş ancak; çatışmanın aldığı biçimler netlikle çözülmemiştir. Çatışma toplumsal olduğuna göre, toplumsal katmanlardan şekillenmektedir. Toplumsal katmanlar ise ekonomi, politik ve ideoloji katmanlarından oluşmaktadır. Bu çerçevede çatışma, biçim olarak ekonomi, politik veya ideoloji başat biçimler almaktadır. Dönemsel olarak öne çıkan çatışma biçimi farklılıklar içermektedir. Dolayısıyla ilgili literatüre katkı için, toplumsal çatışmanın dönemsel olarak aldığı farklı biçimleri ortaya koymak önem taşımaktadır. Çatışmanın biçimleri tespit edilince çözüm önerilerini ortaya koymak daha kolaylık taşıyacaktır.

Bu bağlamda, bu çalışmada amaç; çatışma teorisi çerçevesinde modern dönem toplumsal çatışmayı, tarihsel ve yapısal olarak serimlemeye çalışmaktır. Çalışmanın önemi; çatışma teorisi, uzun yıllar boyunca toplumsal çatışmayı, önemli bir toplumsal açıklama aracı olarak, genel olarak; kaynakları, süresi, sonucu gibi boyutlardan hareketle ele almıştır. Bu çalışmada ise toplumsal çatışmanın ekonomi, siyaset veya ideoloji açısından aldığı farklı biçimler, bütüncül perspektiften ortaya konulmaya çalışllacaktır. Çalışmanın kapsamı; modern sonrası dönem toplumsal çatışmanın tarihsel gelişimidir. Çalışmanın hipotezi; toplumsal çatışma, kapitalizmin farklı evreleri boyunca farklı biçimler almıştır. Sanayi devriminin başlarında çatışma, ekonomik başat bir biçime bürünürken, ilerleyen dönemde ideoloji başat bir biçime dönüşmüş ve kapitalizmin küreselleşme evresinde politik başat bir biçim almıştır.

\section{Bir Toplumsal Olgunun Yapısal Görünümü: Toplumsal Çatışma ve Toplumsal Çatışmanın Biçimleri}

Toplumsal yapı, ekonomi, siyaset ve ideoloji gibi toplumsal katmanların eklemlenmesinden oluşmakla birlikte yapıya biçim veren, toplumsal olgunun eklemlerin dolayımlanmasıdır. Bu çerçevede toplumsal olgu, ekonomi, siyaset ve ideolojinin dolayımlanmasından şekillenmektedir. Toplumsal yapının eklemlerin, tarihsel olarak dolayımlanmasında ortaya çıan boşluk, toplumsal çatışmayı yaratmaktadır çünkü bir toplumsal yapı ne kadar sağlam eklemlense de toplumsal farklılıklar toplumsal yapının katmanları arasında boşluk yaratmaktadır. Farklılıklar, toplumsal katmanların, taleplerine 
cevap vermediği oranda tepkide bulunmaktadır. Çatışma, bu ortamdan doğmaktadır.

Çatışma teorisyenleri çatışmayı, toplumsal değişim temeline yerleştirmektedir. Özellikle, devrimsel boyutta değişimlerin temelinde, çatışmanın şiddetlenmesi ve bunun uzantısı olan işlevsel zor kullanma gerçekleşmektedir. Bu dönemler aynı zamanda niceliksel evrim sonucunda, niteliksel değişim anlamına gelmektedir. Ancak çatışma, özellikle kontrollü bir çatışma, toplumsal değişimin temelinde olmakla birlikte, aynı zamanda, toplumsal düzenin de temelinde yer almaktadır. Toplumsal yapının eklemlerinin bir bütün olarak sürdürülmesi veya başka bir deyişle toplumsal düzenin sürdürülmesi için çatışma ve onun doğal refleksi olan işlevsel zor kullanma gerekli olmaktadır. Toplumsal yapının en üstünde yer alan siyasal iktidar ile meydan okuyucu gruplar arasında çatışma, eğer iktidar sahibinin gücüyle bastırılıyorsa bu, toplumsal yapının eklemlerinin bütünlügünün korunması anlamına gelmektedir. Böylece çatışma, devrimci değil evrimci bir karaktere bürünmektedir. Eğer meydan okuyucu grup, kullandığı işlevsel zor ile toplumsal yapının eklemlerini parçalayabilirse, bu, devrimci bir değişim anlamına gelmektedir. Bir bakıma tarih, siyasal iktidar sahipleri ve meydan okuyucular arasında gerçekleşen çatışmanın bütünselliğinde gerçekleşmektedir. Diyalektik olarak yeni, eskinin içinde doğup büyüdüğü için eski toplumsal yapının, belirli bir süre varlığını sürdürmesi gelişme için gereklidir. Dolayısıyla toplumsal yapının, yenisine yerini bırakana kadar, varlığını sürdürmesi yapısal bir durumdur. Bu durum, farklı çıkarların birleşiminden oluşan toplumsal yapıda ve o yapının ürettiği çatışmada ancak, zor gücüyle sağlanmaktadır. Zorun niceliksel ve niteliksel boyutu, toplumsal yapının sonucuna karar verebilmektedir. Siyasal iktidar sahibinin veya meydan okuyucunun kullandıkları zor, toplumsal değişimin evrimci veya devrimci bir niteliğe ulaşmasına yol açmaktadır.

Toplumsal çatışmanın biçimleri için işlevsel, davranışsal veya Marksist yaklaşımlar tarafından farklı açıklamalar geliştirilmektedir. Öncelikle bir durumun toplumsal çatışma olarak tanımlanması için belirli koşulların gerçekleşmesi gerekmektedir. Bir çatışmanın toplumsal çatışma olarak tanımlanması için, insanların diğer gruba muhalefet eden, bilinçli grup olarak harekete geçmesi gerekmektedir (Kriesberg, 1973: sf. 46). Bu tanımlamadan hareketle, grupların bilinçlenmesiyle toplumsal yapının katmanları arasında bağlantı kurulabilir. Bu ilişki, toplumsal çatışmanın değişen niteliği ve di- 
namikleri hakkında açıklayıcı zemin sağlayabilecektir. Toplumsal yapının temel katmanları olarak ekonomi, siyaset ve ideoloji katmanları ile grupların bilinçlenmesi arasında nesnel bir bağ kurulabilir. Toplumsal katmanların eklemlerinin çözüldüğü noktada, toplumsal çatışmanın dinamikleri yer almaktadır.

Bu bağlamda temel soru; farklı çıkar gruplarının, çıkarlarının bilincine varmasına hangi belirleyen sebep olmaktadır? Bu soruya verilecek cevap, aynı zamanda, toplumsal çatışmanın aldığı biçim hakkında gerekli bilgiyi de verecektir. Toplumu bir ilişkiler bütünü olarak kabul ettiğimiz noktada, ilişkilerin biçimi, toplumsal çatışmayı temel olarak belirleyen katmanı da vermektedir. Burada insanlığın ilk ilişkisini incelersek, temel ilişkiyi, dolay1syyla toplumu kuran temelleri anlamak mümkün olacaktır. Karl Marx ve Friedrich Engels'e göre ([1846] 2018, s.34); “Toplumsal yapı ve devlet daima belirli insanların yaşam süreçlerinden doğup gelişir...fakat bu bireyler...maddi üretim yapan bireylerdir; dolayısıyla, kendi iradelerinden bağımsız belirli maddi sınırlamalar, ön kabuller ve koşullar altında çalışan bireylerdir." Buradan hareketle, toplumu kuran ilişkilerin ekonomi olduğu sonucuna varabiliriz. Dolayısıyla toplumsal çatışmanın aldığı biçimi, ekonominin gelişimine bağlayabiliriz. Ekonominin gelişim seviyesi veya modern anlamda kapitalizmin gelişimi, toplumsal çatışmanın aldığ 1 biçimi de gösterge olarak sağlayabilir.

Toplumsal çatışmanın, farklı niteliklerde çıkarların birbiriyle çelişmesi sonucu somutlaştı̆̆ ileri sürülebilir. Farklı nitelikte çıkarlar ise toplumsal olarak, ekonomik, siyasal veya ideolojik biçimlerde karşımıza çıabilmektedir. Ekonomiyi temel belirleyen olarak ortaya koyduğumuz zaman; insanlar, temel çıkar olarak türünü sürdürebilmek için, ilk anda, ekonomik çıkar çatışmasına girmektedir. Sınırlı ekonomik kaynaklara sahip olma mücadelesi, toplumsal çatışmanın temel özelliği sayılabilir. V. I Lenin'e göre ([1896] 2011, s.5); "insanların, kendi ihtiyaçlarını karşılamak için gerekli şeylerin üretiminde birbirleriyle girdikleri ilişkiler, üretici güçlerin gelişimine dayalıdır." Dolayısıyla, kapitalizmin başlarında üretici güçler -emek ve sermayegelişme seviyeleri, ekonomik açıdan çatışmaya yol açıyordu. Emek ve sermaye, artıktan daha fazla pay almak istiyordu. Ekonomik çatışmanın belirli bir aşamasından sonra, ekonomik çıkar çatışması ideolojik bir biçim almaktadır. Bu aşamada amaç, ideolojik olarak kapsanma, içerilme sorunsalıdır. Kenneth Minogue'a göre (1994, s.20) ideoloji; “toplumu yöneterek sosyal 
mükemmeliyeti yaratma projesidir.". Bu açıdan ideolojik çatışma biçimi, yalnız bir kapsanma sorunu değil, aynı zamanda topluma biçim verme mücadelesidir. Ekonomik gelişme sonucu belirginleşen farklılıklar, bu aşamada topluma, kendi çıkarlarına uygun yön verme amacına yönelir ve burada temel motivasyon ideolojidir. Son aşamada, toplumsal çatışmanın politik bir boyut alması gözlenmektedir. Siyasal anlamda bir güç olma ve değerlerin dağıtımından politik olarak pay alma mücadelesidir. Toplumsal çatı̧̧ma, toplumsal yapıya benzer şekilde bütünsellik içermektedir ve ekonomik başat çatışma aynı zamanda politik ve ideolojik çatışmayken, politik başat çatışma, ekonomik ve ideolojik çatışma ve ideoloji başat çatışma da ekonomik ve politik çatışma olarak yaşanmaktadır. Ekonomi, ideoloji veya politikayı tek boyutlu varsaymak, gerçekliğin bütüncül yapısını gözden kaçırmaya yol açabilir.

Toplumsal çatışmanın dinamiklerini anlamak için nesnel dünyanın evrimini de anlamak gereklidir. Gerek çatışma teorisi ve gerekse de son dönem yaygınlık kazanan sosyal kimlik teorisine göre nesnel koşullar, toplumsal çatışmayı anlamak için önemli bir temeldir. Bu çalışmada, toplumsal yapının katmanları arasında eklemlerin bütünlüğünü sağlayan ayrıcalıklı katman, ekonomi olarak tanımlanmaktadır ve bu çerçevede son ekonomi üretim tarzı olarak kapitalizm ve kapitalizmin evrimi temel olarak alınmaktadır. Bu çerçeveden hareketle, toplumsal çatışmanın niteliğini anlamak için kapitalizmin evrimi ve bu evrim sırasında öne geçen toplumsal katmanları ortaya koymak gereklidir. Toplumsal katmanların hiyerarşisi, toplumsal çatışmanın biçimleri hakkında bir çerçeve sağlayabilecektir.

\section{Kapitalizmin, Politikanın ve İdeolojinin Evrimi}

Toplumsal çatışmayı verili kabul edersek, küçük, orta ve büyük çaplı çatışmaların niteliğinin, statik değil dinamik olduğunun tespit edilmesi tarihsel çerçevede bir sonuçtur. Çatışma, toplumsal bir olgu olduğuna göre, toplumsal yapının ekonomi, politika ve ideoloji gibi katmanlarının, toplumsal çatışmanın niteliğini belirlediğini olgusal olarak kabul edebiliriz. Bu noktada vurgulanan toplumsal çatışma, herhangi bir toplumda kısa dönemler görülen günlük çatışmalar değil, daha uzun erimli konjonktür çatışmalardır. Tarih, Fernand Braudel'in ileri sürdüğü gibi çeşitli zamanlara bölünmekte ve herhangi bir olgu ile ilgili analiz yapıldığı zaman tarihsel gelişimden 
referans almak gereklidir. Braudel tarihi, kapitalizmin tarihi (yapısal tarih), kapitalizmin içinde belirli uzunlukta dönemler (konjonktür tarih) ve kapitalizmin içerisinde kısa dönemler (olayların tarihi) olarak üçe ayırmaktadır (Braudel, [1985] 2015). Temel toplumsal çatışmanın niteliği, Braudel'in orta düzey soyutlama seviyesi olan konjonktür tarihte karşımıza çıkmaktadır. Uzun dönemli yapısal çatışma, daha kapsamlı bir incelemeyi gerektirmektedir ve bu çalışmanın kapsamı dışındadır. Yapısal tarih içinde toplumsal çatışma incelense de, değişen nitelikler anlaşılmayabilir. Kısa vadeli çatışma ise toplumsal çatışmayı anlamak için gerekli verileri sağlamamaktadır. Olayların tarihi, somut çatışmaları sağlamakla birlikte genelleme yapılması için uygun değildir. Konjonktür tarih içinde toplumsal çatışmanın değişen niteliği, olguyu anlamak için gerekli altyapıyı sağlamaktadır.

Konjonktür tarih içerisinde toplumsal çatışmanın değişen niteliği anlamak için değişimi anlamak gereklidir. Louis Kriesberg'e göre (2009, s.7), toplumsal çatışmanın uzun dönem değişiklikleri, dışsal sosyo-politik çevrede, yeni gelişmelerden ortaya çıkmaktadır. Uzun dönem değişiklikleri, Braudel'in konjonktür tarih çerçevesinde ele alınırsa toplumsal çatışmanın değişen niteliği anlaşılabilecektir. Braudel'in konjonktür tarih ve Kriesberg'in dışsal sosyo-politik çevre veya küresel yapı anlayışı, toplumsal çatışmanın değişen niteliğini analizi için gerekli zemini sağlayabilir.

Tarihsel olarak, ekonomik, politik ve ideolojik üç dönüm noktası, toplumsal çatışmanın niteliğini dönüştüren olaylar olarak anlaşılabilir. Bu dönüm noktaları Braudel'in konjonktür tarihinin dönüm noktaları olarak da kabul edilebilir. Ekonomi katmanında yaşanan üç dönüm noktası; sanayi devrimi (18. yy sonu), büyük tekellerin ortaya çıkışı (19. yy sonu) ve petrol krizi (20. yy sonu) olarak belirlenebilir. İdeolojik olarak üç dönüm noktası ise; bireyci liberal ideolojinin egemen ideoloji olduğu 1789 Fransız Devrimi sonrası (19. yy'da yaşanan dönem), Rus Devrimi (1917) sonrası ideolojik olarak kapitalist-sosyalist ideoloji kamplaşmasının yaşandığı (Soğuk Savaş Konjonktürü) ve SSCB'nin çöküşü (1991) sonrası yükselen kimlikler ideolojisidir. Politik olarak üç dönüm noktası ise; Fransız Devrimi (1789), Rus Devrimi (1917) ve 1968 Hareketleridir. İdeolojik ve politik dönüm noktalarının ekonomik dönüm noktalarından sonra gelmesi aralarında eşzamanlı değil ardışık ilişkiyi ortaya koymaktadır. Ekonominin, politika ve ideolojinin öncülü olduğu tezi için gerekli tarihsel kanıtları sağlamaktadır. Toplumsal 
çatışmanın niteliği, bu üçlü toplumsal katmanın bir sentezi olarak varlık bulmaktadir.

Bu dönüm noktaları, temellerini, bir bütün olarak ekonomik sistemde, bir başka ifadeyle kapitalizmin evriminden sağlamaktadır. Kapitalizmi, üç temel dönem olarak ele almak mümkündür. Birinci aşama; 1789 Fransız Devrimi sonrası kapitalizmin serbest rekabetçi dönemi, ikinci aşama; 19. yy sonu büyük tekellerin ortaya çıkışı veya tekelci kapitalizm aşaması ve son olarak 20. yy sonu gerçeklik bulan küreselleşmiş kapitalizm aşamalarıdır. $\mathrm{Bu}$ üç dönem, toplumsal yapının katmanları olan politika ve ideolojide de köklü dönüşümlere yol açmıştır. Bu dönüşümler, toplumsal çatışmanın biçimlerini de temelden etkilemiştir.

Kapitalizm, sonsuz sermaye birikimi rejimidir. İlksel birikimini yaparken en temel çelişki, sermaye ve işçi sınıf arasındadır. Bu çerçevede emek gücü, sermaye ile artı-değerin bölüşümü konusunda çatışmaya girmektedir. Bu durum doğrudan ekonomi başat, ideolojik ve politik çatışma durumudur. Emek gücü ve sermaye, yalın ve düz bir şekilde karşı karşıya gelmiştir. Bir yandan emek gücü ile sermaye çatışırken bir yandan da sermaye birikiyordu. Bu dönem, kapitalizmin serbest rekabetçi döneminin bir sonucudur.

19. yy sonu kapitalizm, yeni bir biçime evrilmiştir. Bu evre kapitalizmin tekelci aşamasıydı (Sweezy ve Baran [1966] 2007). Büyük tekeller tüm ekonomik hayatı kontrol altına alıyordu. Bu dönemde iki dünya savaşı yaşanmıştır. 1917'de Rus Sosyalist Devrimi gerçekleşmiştir. Sermaye, bir derece birikmiş ve kitle üretimine geçilmiştir. Bu aşamada, işçi sınıfı belirli bir hayat seviyesi yakalamıştır. Artık toplumsal çatışmanın yeni ekseni, toplum içinde işçi sınıfının ideoloji başat ekonomik ve siyasal mücadelesiydi. Yine toplumlararası platformda ise kapitalist blok ve sosyalist blok arasında ideoloji başat ekonomik ve politik rekabetidir.

Son aşama ise kapitalizmin küreselleşme dönemidir. Neoliberal dönem olarak da adlandırılmaktadır. (Kazgan, 2016). 20. yy sonu gerçekleşmiş ve kapitalist üretim esnek üretime geçmiştir. Bu dönem yeni çıkar grupları, sermaye birikiminin geldiği aşama ile ortaya çıkmış ve kimlikler en önemli unsur haline gelmiştir. Artık kapitalizmin küreselleşme aşaması ile birlikte toplumsal çatışmanın ekseni siyasal başat ekonomik ve ideolojik mücadele haline gelmiştir. Bütün bu süreç kapitalizmin evrimi ve sermaye birikiminin geldiği aşama tarafından biçimlenmiştir. 


\section{Ekonomik, Siyasal ve İdeolojik Toplumsal Çatışmanın Evrimi}

Çatışma olgusunun, kapitalizmin tarihsel evriminde, ekonomi başat, ideoloji başat ve politik başat biçimler aldığını belirtmiş̧tik. Bir toplumsal olgu olarak toplumsal çatışmanın görüngüleri de, toplumsal katmanların eklemlerinin çözülmesinden açığa çıkmaktadır. Ekonomi, politik ve ideoloji krizleri, çatışmanın derinleşmesine yol açmaktadır. Bu bir anlamıyla yönetim krizidir. Bu dönemlerde, yönetim, tartışmaya açılmaktadır.

Kapitalizmi bir ekonomik sistem olarak ele aldığımız zaman, ekonomik sistemin temeli olan sermaye birikimi ve gelişimi, toplumsal çatışmayı da şekillendirmektedir. Sermaye birikiminin başlarında, temel motivasyon, daha fazla birikim olduğu için toplumsal çatışmanın temel niteliğinin ekonomik olduğunu ileri sürmüştük. Kapitalist üretim tarzının temel aktörleri olan ücretli işçi ve sermaye arasında, artı-değerden daha fazla pay alma mücadelesi, toplumsal çatışmaya ekonomik bir nitelik kazandırmaktadır. $\mathrm{Bu}$ durum ekonomi başat, politik ve ideolojik mücadeleye yol açmıştır.

Karl Marx'ın yaşadığı dönem olan 19.yy, modern kapitalizmin doğum yıllarıydı. Kapitalizm, ekonomik bir kavramdır (Dahrendorf, [1957] 1959, s.37) ve doğum yıllarında toplumsal çatışmanın temeli, ekonomikti. Çatışma, burjuvazi ve işçi sınıf arasındaydı ve temel anlaşmazlık konusu, işçi sınıfının üretimden alacağı pay ve çalışma koşullarıydı. 19. yy ekonomik dünyası hakkında inceleme yapan Eric Hobsbawm ( [1995] 2017a, s.84), 19. yy. boyunca gerçekleşen ekonomik temelli çatışmaların temel toplumsal sorun olduğunu ve kapitalizmin sınırsız gelişimine uygun kurum ve politikaların uygulamasıyla çözüldüğünü; kapitalizmin genişlemesi ve insanların memnuniyetsizliği arasında uygun mekanizmaların kurulmasıyla -istihdam ve göç- çözüldüğünü belirtmektedir. Bu çerçevede toplumsal çatışma, ilgili toplumsal katman tarafından kapsanma sorunsalından çikmıştır. Toplumsal katmanın kapsama kapasitesi genişledikçe farklı çıkarların çatışma şiddeti düşmektedir. Kapsama kapasitesi daraldıkça çıkarların çatışması şiddetlenmiştir.

Tarihsel gelişim sürecinde toplumsal çatışmaların biçimlerine bağlı olarak çatışma, pratik olarak farklı görünümlere sahip olmuştur. Pratiğin tezahür biçimi, toplumsal çatışmanın biçimine bağlı olarak şekillenmiştir. Ekonomi başat toplumsal çatışma dönemi olan 19. yy boyunca çatışmanın tezahür biçimleri olan grevler, makine kırıcılar (Luddite) ve devrim hareketleri - 
1848 Devrimleri-, kısaca tüm olaylar, ekonomi temelli toplumsal çatışma biçimlerini yansıtmıştır (Hobsbawm, [1975] 2016, s.48).

Kapitalizmin gelişmesi ve sermaye birikiminin gelişmesi ile birlikte toplumsal çatışma, yeni bir evreye girmiştir. Bu aşamadan sonra çatışma, ampirik olarak, ideolojik bir biçime evrilmiştir. Özellikle, 1917 Rus Devrimi'nden sonra dünya, iki kutuplu bir yapıya dönüşmüş ve bir yanda ABD merkezli liberal kapitalist blok öteki yanda ise SSCB merkezli sosyalist blok varlık kazanmıştır. Bu iki blok merkezli ideolojik başat biçimli bir çatışma uzun yıllar gözlenmiştir.

20. yy'ın ilk yarısında, sınıf temelli, sağ ve sol ideoloji yükselişe geçmiştir (Berg ve Janoski, 2005, s.73). I. Dünya Savaşı'nun sonundan SSCB'nin çöküşüne kadar ideoloji, çatışmanın temel kaynağıydı (Shtromas, 1997, s.31). Özellikle dünya, kapitalist, sosyalist ve faşist rejimlerin ideolojik mücadelesi ile şekillenmiştir. Bu dönem temel aktörler devletlerdi. Aralarında keskin bir güç mücadelesi vardı. Amaç; ideolojilerin etki alanlarını, dünya üzerinde, mümkün olan en geniş kapsamlı yaymaktı. Bu dönemi Eric Hobsbawm, ideoloji temelli aşırılıklar çağı olarak tanımlamıştır ve bu dönemi; I. Dünya Savaşı'nın başlangıcı olan 1914'den SSCB'nin çözülüşü olan 1991'e kadar belirlemiştir (Hobsbawm, 1994).

Hobsbawm ([1987] 2017b, s.98), 19. yy başından sonuna doğru yaşanan ekonomik çatışmadan sonra, özellikle 1871 Paris Komününden sonra yeni toplumsal çatışmanın biçimini ideoloji temelli politik çatışma olarak tanımlamaktadır. Politik çatışmanın kökeninde temel sorunsal, demokratikleşme sorunsalıdır, bir başka ifadeyle ideolojiktir. Demokratikleşme ile birçok farklı toplumsal sınıf ve grup, kapsanma veya içerilme hakkına kavuşmaktadır. Dolayısıyla 19. yy sonundan 1914 Birinci Dünya Savaşı'na gelirken temel sorunsalın ideolojik olduğu ve temel mücadelenin ideolojik olarak içerilme sorunsalı olduğu ileri sürülebilir. Hobsbawm ([1987] 2017b, s.99), 19. yy sonunda, kadın nüfusu bir yana bırakıp, erkek nüfus için bile seçme ve seçilme hakkından mahrum bırakılmasının ideolojik ve siyasal gerginliğe yol açtı̆̆ını belirtmektedir. Dolayısıyla, ekonomik çatışma biçiminden sonra ideolojik çatışmanın gerçekleşmesi, toplumsal gelişimle uyumlu bir çerçevede gerçekleşmiştir.

İdeoloji başat toplumsal çatışma dönemi, 20. yy başı ile sonu arasında, devletlerarası savaşlar ve diplomatik mücadele, toplumsal çatışmanın ideoloji temelli tezahürleridir. İdeolojik temelde kutuplaşmış devletler, araların- 
da, güç mücadelesine girmiş ve toplumsal çatışma devletlerarası boyut kazanmiştır.

Tekelci sermayenin derinleştiği 20. yy'da önemli bir kırılma noktası da 1968 gençlik hareketleridir. Bu olay, toplumsal çatışmayı yeni bir aksa yerleştirmiştir. 1968 ile toplumsal cinsiyet talepleri, gençlik talepleri ve etnik talepler yükselişe geçmiştir. Bu dönemi takip eden 1991'de, SSCB'nin çöküşü ve reel sosyalizmin gerilemesi ile birlikte, toplumsal çatışma politik başat bir görüngü almıştır. Kimlikler ön plana çıkmıştır ve temel toplumsal çatışma, farklı kimlikler arasında politik olarak yaşanmıştır. Bundan sonra toplumsal çatışma, politik başat, ekonomi ve ideoloji temelli mücadeleye dönüşmüştür. Yükselen etnik politik çatışma, en çok potansiyel istikrar bozucu bir güç olarak, insanlığın karşısına, Soğuk Savaş sonrası dönemde gerçeklik kazanmıştır (Ross ve Rothman, 1999, s.1).

1968 öğrenci hareketleri ve daha sonrasında ortaya çıkan yeni sosyal hareketler sonucu çatışmanın başat öğesi ideoloji haline gelmiştir. $\mathrm{O}$ zamana kadar realist temellere sahip çatışma teorisi, yeni unsurlar eklenerek sosyal kimlik teorisine evrilmiştir. Klasik çatışma teorisi; realist olarak, çatışmayı, nesnel ve dişsal sebeplerin bir sonucu olarak kabul ederken, sosyal kimlik teorisi; nesnel ve dışsal sebepleri kabul etmekle birlikte bunun yanında, psikolojik faktörleri de çatışmayı anlamak için eklemiştir (Ramiah, Hewstone ve Schmid, 2011, s.46). Artık dünya, farklı kimliklerin, uyumsuz amaçları arasındaki çatışmaları göstermektedir. Etnik, gender, dinsel, medeniyet kimlikleri arasında ideoloji başat bir çatışma varlık bulmuştur. Özellikle SSCB'nin çöküşünden günümüze farklı kimlikler arasında çatışma yaygınlık kazanmıştır.

1970'lerin sonundan itibaren geleneksel sınıf temelli çatışmalar geri çekilirken, kimliklerin alternatif çeşitleri -1rk, gender, din, etnisite- yükselişe geçmiştir. Bu dönem bir bakıma kimlik temelli politikalarn yükselişe geçtiği dönemdir (Berg ve Janoski, 2005, s.73). Sınıfsal çatışma, görüngü olarak, yerini kimlik temelli çatışmalara bırakmıştır. Aslında kimlik temelli çatışmanın temelinde ekonomik ve ideolojik sorunlar bir olgu olarak durmaktadır. Ancak görünüm, kimlik temelli politik başat bir çatışmadır. Bu dönem, artık, sağ-sol ideolojik çatışmaların yerine, bireycilik, özgürlük ve insan hakları gibi politik idealler uğruna çatışmalarla biçimlenmiştir (Shtromas, 1997, s.31). 
20. yy sonundan itibaren politik başat toplumsal çatışma dönemi olarak kabul edilen süreçte, terör ve iç savaşlar analiz edilmeye başlanmıştır. Dünya, bu dönem, yüksek maliyetlere sahip toplumsal çatışmayı yaşamıştır. Kimliklerin politik hak talepleri, legal veya legal olmayan biçimde politik düzlemde yükselen talepleri bu dönemin karakteristik özelliğidir. Bu dönem temel talep, politik, ekonomik ve ideolojik olarak kapsanma talebidir. Dar olarak tanımlanan politikanın bu dönem, kapsamının genişletilmesi ve yeni bir politik, ekonomik ve ideolojik toplumsal yapının inşası bu dönemin en önemli gündemidir.

Tablo 1. Modern Dönem Toplumsal Çatışma

\begin{tabular}{llll}
\hline Tarihsel Dönem & $\begin{array}{l}\text { Toplumsal Çatışma } \\
\text { Biçimleri }\end{array}$ & $\begin{array}{l}\text { Çatışmanın Ana } \\
\text { Aktörleri }\end{array}$ & $\begin{array}{l}\text { Çatışmanın Görünüm- } \\
\text { leri }\end{array}$ \\
\hline 19. yy $\mathbf{- 1 9 1 4}$ & Ekonomik & Sinıflar & Grevler - Devrimler \\
1914-1980'ler & İdeolojik & Devletler & $\begin{array}{l}\text { Devletlerarası Savaşlar } \\
\text { - Devrimler }\end{array}$ \\
& & Terör - İç Savaşlar \\
\hline
\end{tabular}

\section{Sonuç}

Toplumsal yapı, toplumsal yapının ekonomi, politika ve ideoloji katmanlarının eklemlenmesinden oluşmaktadır. Toplumsal yapının katmanları arasındaki ilişki dolayımlanma ilişkisidir. Ekonomi, politika ve ideoloji katmanları dolayımlanarak bir bütün oluşturmaktadır. Eklemlerin çözüldüğg̈ noktada, toplumsal yapının bütünlüğü sarsılmaya başlamaktadır. Bu çözülmenin oluştuğu noktada gerçekleşen boşluk, toplumsal çatışma için gerekli nesnel koşulları sağlamaktadır. Toplumsal yapının bütünlüğünün bozulması, yöneticilerin yönetememe krizi anlamına gelmektedir. Bu koşullar altında toplumu oluşturan farklılıklar, derin bir çatışma pozisyonu alırken, farklılıklar arasındaki çatışma da tarihsel olarak farklı yapılar altında ortaya çıkabilmektedir. Farklılıklar arasındaki çatışma, tarihsel olarak farklı biçimler almaktadır.

Dünya, farklılıkların bir arada bulunduğu hiyerarşik bir yapıya sahiptir. Toplumsal yapının katmanlarının dolayımlanması, bu hiyerarşik yapının sürdürülmesini sağlamaktadır. Eğer, toplumsal katmanlar çözülürse ortaya, toplumsal çatışma durumu çıkmaktadır. Toplumsal çatışma; ekonomi, politika veya ideoloji temelli gerçekleşmektedir. Görünüm olarak ekonomi, 
politika veya ideoloji baskın olsa da çatışma, bütünseldir. Dolayısıyla ekonomi başat bir çatışma aynı zamanda politik ve ideolojik çatışma iken; politik başat çatışma ekonomik ve ideolojik çatışmadır ve ideoloji başat çatışma da ekonomik ve politik çatışmadır. Burada toplumsal çatışmanın biçimini belirleyen, kapitalist sermaye birikiminin geldiği aşamadır. Birikimin başlarında veya ilkel birikim dönemi çatışma, ekonomi başat bir çatışma iken birikimin ilerleyen aşamalarında çatışma, politik başat bir çatışmaya dönüşmüş ve daha ileriki sermaye birikimi aşamasında ideoloji başat çatışma biçimini almıştır.

Toplumsal çatışmanın aldığ 1 biçimleri kapitalist sermaye birikimine dayandırdığımız zaman, kapitalizmin evrimi önem kazanmaktadır. Kapitalist üretim tarzının dönüm noktalarına baktığımız zaman, 19. yy'da serbest rekabetçi kapitalizm dönemi, 19. yy sonunda tekelci kapitalizm dönemi ve 20. yy sonunda küresel kapitalist üretim ve küreselleşme gözlenmektedir. Bu çerçevede kapitalizmin dönüm noktaların;; 19. yy başından 1873 krizine kadar serbest rekabetçi kapitalizm, 1873 krizinden 1980'lere kadar tekelci kapitalizm dönemi ve 1980 'lerden günümüze küresel kapitalist üretim ve küreselleşme dönemi olarak adlandırabiliriz. 19. yy başından sonuna kadar toplumsal çatışmanın aldığı biçim, emek gücü ile sermaye arasında ekonomik başat çatışmadır. Makine kırıclığından, 1848 devrim hareketlerine kadar tüm göstergeler, ekonomik çatışmayı göstermektedir. Ekonomik olarak 1873 ekonomik krizi ve politik olarak 1871 Paris Komünü bu dönemin dönüm noktaları olarak tarihsel anlamda gerçeklik bulmuştur.

1873 ekonomik krizinden sonra ortaya büyük tekeller tarafindan denetlenen bir kapitalist üretim aşaması çıkmıştır. Politik anlamda iki yeni ideoloji varlık bulmaya başlamıştır. Bu iki yeni ideoloji, Rusya'da sosyalist ideoloji ve İtalya, Almanya'da faşist ideoloji olarak ileriki tarihlerde uygulama aşamasına geçmiştir. Artık temel toplumsal mücadele, ekonomiden politik başat bir biçime doğru evrilmiştir. Bu dönemin politik dönüm noktaları 1917 Rus Devrimi ve Dünya Savaşlarıdır. Diplomatik mücadelelerden savaşlara kadar tüm göstergeler, politik çatışmayı göstermektedir. Dünya coğrafyası, liberal kapitalist, sosyalist ve faşist rejimlerle kutuplaşmıştır. İdeolojik temelli varlık bulan devletler, bu dönemin temel aktörleri olmuştur. İdeolojik güç mücadelesi, üçüncü dünya devletleri arasında süren savaşlarla görünüm olarak kendisini ortaya koymuştur. 
1968 küresel gençlik hareketleri, kapitalizmin evriminde yeni bir dönüm noktası olarak kendisine yer bulmuştur. Ortaya çıkan gençlik hareketi, gender, etnik, din, rrk ve diğer kimlikler temelinde politik bir biçim kazanmaya başlamıştır. 1991 yılında SSCB'nin dağılmasıyla kimlik temelli söylemler yükselişe geçmiştir. Artık temel toplumsal çatışma politik başat ekonomik ve ideolojik çatışma biçimi almıştır. Bu dönemin toplumsal çatışma görünümleri, terörizm ve iç savaş biçiminde kendisini göstermiştir. Bu dönemde politik tanınma meselesi kimlikler için temel hedef anlamına gelmiştir.

Sonuç olarak; tarihsel açıdan, modern dönemlerde, çatışmanın görüngülerinin sanayi devriminin başlarında bir başka ifadeyle henüz sermaye birikiminin yeterince gelişmediği dönemlerde, ekonomi başat çatışma biçiminde gerçekleştiği ileri sürülebilir. Yine, daha sonraki süreçte kapitalizmin geliştiği, büyük tekellere dönüştüğü tekelci sermaye dönemi toplumsal çatışma ideoloji başat çatışma biçimini almıştır. Son olarak, kapitalizmin küreselleştiği, küresel kapitalist üretimin öne çıktığı dönemde ise politik başat bir biçim aldığını ileri sürmek mümkündür. 


\title{
EXTENDED ABSTRACT
}

\section{An Analysis on Changing Forms of Historical-Social Conflict in the Context of Conflict Theory}

\author{
İnan Akdağ \\ Amasya University
}

Conflict theory has theorized that daily life consists of diversities and that these diversities build on mutual conflicts because of inharmonious interests. Society from micro, meso to macro groups includes tensions and conflicts in its structure. Conflict theory emphasizes inharmonious needs and interests of different people and different groups. Conflict realizes at all stratums of social life. Gender, ethnic conflicts, religious conflicts, international conflicts and interclasses conflicts are fault lines of social conflict; and they appears at first sight. The most common conflict is for distributing of scarce materials and for financial sources. With another sight, the main conflict appears from economy. However, conflict took ideological and political shapes especially in the end of 20th century. According to conflict theory, conflict is a process. Conflicting interests are hidden until a group is to mobilize for active struggle. Therefore, when the world is to be fiction of social life over, it is not enough for conflict theory that there are differences. The necessary element for conflict theory is that an interest group which has consciousness for these differences starts to move for struggle. Consciousness and praxis appear as adjunct elements completing conflict process.

Conflict theory identifies with Karl Marx and Marxism for long years. Marx, who defined class conflict as development engine of history universally, determines dialectical union of polar. Conflict, at this meaning, has a basic function for establishing and continuing social structure. In addition, non-Marxist conflict theory became important after 1968 Global movements. After 1968, the conflict theory including other social groups (gender, ethnicity, religious, and civilizations) instead of Marxist economic class conflict theory had been developed. The main difference between Marxism and contemporary conflict theories is when Karl Marx puts forwards class conflict; contemporary conflict theories emphasize interest conflict. Therefore, contemporary conflict theory studies social conflict from broader perspec- 
tive instead of economic class conflict theory of Marxism. Conflict theory has gained variety among contemporary sociologists. According to Lewis Coser, who is representative of functionalist approach claims that social conflict is a struggle on values and claims for scarce statues, power and sources. According to Ralf Dahrendorf, class conflict has displayed differences in contemporary industry society since the first appearance of industry society. Conflict intensity softened with conflict regulations which are realized by the end of change in state and industry entrepreneurs. Conflict intensity reduced when institutionalism increased. Likewise American structural-functionalism which is active until the 1960s was excluding conflict. According to Talcott Parsons, who is important represent of structuralfunctionalism, society is a community which establishes on value compromise.

Conflict theory came into question after the 1960s with 1968 social movements. Civil rights protest, anti-war movement, woman movements protest led to revive social conflict again. Behaviorism is also among contemporary conflict theory. According to behaviorism, inharmonious purposes, solidarity, organization, mobilization, hostility and sources bring about conflicting behaviors. According to Randall Collins, who is represent of behavior theory, the axe of conflict is among stratums and stratums are defined by variables which are groups, ethnicity and education level. Conflict appears from different behaviors. When relevant literature is studied, conflict doctrinaires put forward conflict situation; however, the shapes of conflict from holistic perspective are not put forward. Conflict is defined; necessary elements for conflict are determined; ties between conflict and society are defined; however, the shapes of conflict are not put forward. Because conflict is social phenomenon, conflict is defined by social stratums. Social stratums consist of economy, ideology and politics. Therefore, at this framework, conflict shapes as economic, ideological and political dominant types. Periodically, type of conflict takes different types. Therefore, in order to make contribution to relevant literature, it is important that different types of social conflict should be exhibited. If the types of conflict are determined, it is easy to give answer to problems which are sourced by conflict. In this context, the purpose of this study is to exhibit historically and structurally social conflict during modern period. The importance of study is that conflict theory was revealed social conflict from dimensions like sources, 
duration, results; however, in this study economic, political, ideological shapes of social conflict are to be put forward from holistic perspective. The scope of this study is the historical development of social conflict after modern period. The hypothesis of this study is that social conflict has taken different shapes during different phases of capitalism. Conflict, at the beginning of industry revolution, took economy dominant shape, when it turned into ideological dominant shape oncoming period and when it transformed into political dominant shape during globalization period of capitalism.

\section{Kaynakça / References}

Bartos, O. J. ve Wehr, P. (2002). Using conflict theory. Cambridge University Press

Berg, A. V. D. ve Janoski, T. (2005). Conflict Theories in Political Sociology.. In ed. by T. Janoski, R. Alford, A. Hicks, M. A. Schwartz. The Handbook of Political Sociology, Cambridge University Press

Borgatta, E. F. ve Montgomery, R. J. V. (2000). Encyclopedia of Sociology v. I. New York: Macmillan

Braudel, F. ([1985] 2015). Kapitalizmin kısa tarihi. çev. İ. Yerguz.İstanbul: Say Yayınları Collins, R. ([1975] 2009). Conflict sociology. Paradigm Publishers

Coser, L. (1956). The functions of social conflict. New York: The Free Press

Dahrendorf, R. ([1957] 1959). Class and class conflict in industrial society. Stanford University Press

Durkheim, E. ([1893] 2013). Division of labour in society. Palgrave Macmillan

Hobbes, T. ([1651] 1998). Leviathan. Oxford University Press

Hobsbawm, E. (1994). Age of extremes the short twentieth century 1914-1991. Abacus Book

Hobsbawm, E. ([1975] 2016). Devrim çă̆ı 1789-1848. çev. Bahadır Sina Şener. Ankara: Dost Kitabevi

Hobsbawm, E. ([1995] 2017a). Sermaye çă̆ı 1848-1875. çev. Mustafa Sina Şener. Ankara: Dost Kitabevi

Hobsbawm, E. ([1987] 2017b). İmparatorluk çağı 1875-1914. çev. Vedat Aslan. Ankara: Dost Kitabevi

Johnson, D. P. (2008). Contemporary sociological theory. Springer

Kazgan, G. (2016). Liberalizmden neoliberalizme neoliberalizmin getirisi ve götürüsü. İstanbul: Remzi Kitabevi

Kriesberg, L. (1973). The sociology of social conflict. New Jersey: Prentice-Hall

Kriesberg, L. (2009). Changing conflict asymmetries constructively. Dynamics of Asymmetric Conflict, 2(1), 4-22 
Lenin, V. I. ([1896] 2011). Friedrich Engels.. çev. F. B. Aydar. Friedrich Engels içinde. İstanbul: Agora

Machiavelli, N. ([1532] 2008). Hükümdar. çev. N. Adabağ. İstanbul: Türkiye İş Bankası Yayınları)

Marx, K. ve Engels, F. ([1848] 2008). Komünist manifesto. çev. M. Erdost. Ankara: Sol Yayınları)

Marx, K. ve Engels, F. ([1846] 2018). Alman ideolojisi. çev. O. Geridönmez ve T. Ok. İstanbul: Kor.

Marx, K. ([1859] 1993). Ekonomi politiğin eleştirisine katkı. çev. S. Belli. Ankara: Sol Yayınları

Minogue, K. (1994). Ideology After the Collapse of Communism. In ed. A. Shtromas The End of "Isms"? Reflections on the Fate of Ideological Politics After Communism's Collapse.,. Blackwell Publishers

Parsons, T. (1951). The social system. Free Press

Ramiah, A. A., Hewstone, M. ve Schmid, K. (2011). "Social Identity and Intergroup Conflict". Psychol Study, 56(1), 44-52

Ross, M. H. ve Rothman, J. (1999). Theory and practice in ethnic conflict management. Palgrave Macmillan

Savur, M. (1975). Sociology of conflict theory. Social Scientist, 3(12), 29-42

Simmel, G. ([1908] 1956). Conflict. Conflict and the Web of Group Afiliations. New York: Free Press

Shtromas, A. (1997). Ideology and conflict: Does warfare between '1sms' Belong to past history?. International Journal on World Peace, 14(2), 31-76

Sweezy, P. ve Baran, P. ([1966] 2007). Tekelci sermaye. çev. G. Akalın. İstanbul: Kalkedon Yayınları

Weber, M. ([1922] 2012). Ekonomi \& toplum. Cilt 1, çev. L. Boyacı. İstanbul: Yarın Yayınları

\section{Kaynakça Bilgisi / Citation Information}

Akdağ, İ. (2020). Çatışma teorisi bağlamında tarihsel-toplumsal çatışmanın değişen biçimleri üzerine bir inceleme. OPUS-Uluslararası Toplum Araştırmaları Dergisi, 15(10. Yıl Özel Sayıs1), 5231-5251. DOI: 10.26466/opus.629985 